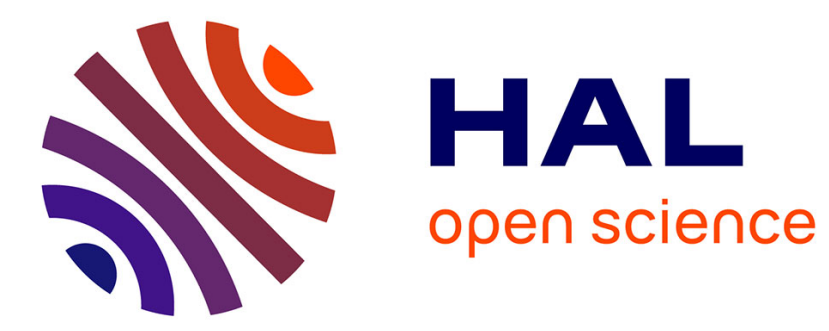

\title{
Experimental Evidence on Gender Interaction in Lying Behavior
}

\author{
Seeun Jung, Radu Vranceanu
}

\section{To cite this version:}

Seeun Jung, Radu Vranceanu. Experimental Evidence on Gender Interaction in Lying Behavior. 2015. hal-01184964v2

\section{HAL Id: hal-01184964 \\ https://essec.hal.science/hal-01184964v2}

Preprint submitted on 26 Oct 2015

HAL is a multi-disciplinary open access archive for the deposit and dissemination of scientific research documents, whether they are published or not. The documents may come from teaching and research institutions in France or abroad, or from public or private research centers.
L'archive ouverte pluridisciplinaire HAL, est destinée au dépôt et à la diffusion de documents scientifiques de niveau recherche, publiés ou non, émanant des établissements d'enseignement et de recherche français ou étrangers, des laboratoires publics ou privés. 


\title{
Experimental Evidence on Gender Interaction in Lying Behavior
}

\author{
RESEARCH CENTER \\ ESSEC Working Paper 1514
}

2015

Seeun Jung

Radu Vranceanu

E 


\title{
Experimental Evidence on Gender Interaction in Lying Behavior
}

\author{
Seeun Jung* and Radu Vranceanu ${ }^{\dagger}$
}

October 2015

\begin{abstract}
The paper reports results from an Ultimatum Game experiment with asymmetric information where Proposers can send to Responders misleading information about their endowment. We allow for all possible gender combinations in the ProposerResponder pairs. Proposer messages that underestimate the actual amount are quite widespread. The frequency of lying is slightly higher in mixed groups. Conditional on lying, men tend to state bigger lies than women. On the other hand, women tend to tell smaller lies when paired with men than when paired with women. In general, women present higher acceptance rates than men.
\end{abstract}

Keywords: Gender studies, Ultimatum Game, Asymmetric information, Lies, Extensive vs. intensive margin.

JEL Classification: J16, D83, C72, C91.

\section{Introduction}

There is a growing body of literature on lying and deception in experimental economics, aiming to reveal what motivates individuals to resort to such questionable communication methods. In an influential paper, Gneezy (2005) shows that when subjects can reap a benefit from lying, many subjects do so, even if this involves a loss for their partner. Another important finding of these empirical studies is that humans present some form of aversion to lying, although its extent can vary greatly from one individual to another (Sanchez-Pages and Vorsatz (2007); Vanberg (2008); Lundquist et al. (2009); Hao and Houser (2010); Charness and Dufwenberg (2006, 2010); Erat and Gneezy (2012); Ariely (2012)). Thus, when they lie, people seldom take the lie to the extreme, as if they were trading-off some benefits from lying against protecting their image of a honest person.

On the other hand, research in psychology has revealed the existence of a significant gender effect in lying behavior, depending on the context and type of lie. In particular, it has been shown that men's lies are more self-oriented, while women's lies are more other-oriented (De Paulo et al. (1996); Feldman et al. (2002)). These findings received support from recent studies in experimental economics (Gill et al. (2013); Conrads et al. (2013); Dreber and Johannesson (2008)), who show that, in experiments where the gender

*ESSEC Business School and THEMA. PB 50105, 95021 Cergy, France. E-mail: jung@essec.edu

†ESSEC Business School and THEMA. PB 50105, 95021 Cergy, France. E-mail: vranceanu@essec.fr 
of the partner is unknown, men resort to selfish lies more often than women do. ${ }^{1}$ This paper aims to take these analyses one step further by studying whether in a typical non-cooperative controlled experiment, not only the gender of the subject but also the gender interaction between the sender and the receiver have an impact on the emergence of dishonest communication strategies. ${ }^{2}$

Several scholars used the asymmetric information version of the Ultimatum Game $(\mathrm{UG})^{3}$ to analyze the extent and consequences of misleading communication in such a non-cooperative setting (e.g., Croson (2003), Boles and Murnighan (2000), Kriss et al. (2013), Besancenot et al. (2013), or Anbarci et al. (2015)). In most of these studies, the endowment of the Proposer is private information to him; he is allowed to make an unverifiable and not-binding statement about this endowment to the Responder, and then he must make an offer to the Responder; the latter sees the offer and the message, and must decide whether to accept the offer or turn it down. If he rejects the offer, payoffs of both players are set to zero, in a move that, contrary to the Dictator Game, provides the Responder with some retaliation power. In general these studies show that Proposers systematically claim to have received an endowment lower than the actual endowment. As it has been argued by Besancenot et al. (2013) by means of a simple model, if (1) Responders have fairness concerns and (2) there are at least some Proposers who always tell the truth (have very high lying costs), it is in the interest of the other Proposers to understate the amount received because Bayesian Responders would (partially) trust them, and would therefore accept lower offers. ${ }^{4}$

Our methodology builds on the experimental design by Besancenot et al. (2013), with the notable difference that subjects are now aware of the gender of their (anonymous) partner (Jung and Vranceanu (2015)). In a nutshell, at the outset of typical round, the computer draws the Proposer's endowment form the set of integer numbers [50;100]. The Proposer makes an offer and simultaneously sends an unverifiable message to the Responder, indicating the amount of the endowment. Obviously, he/she can tell the truth, or lie by communicating a different endowment than the actual one. It will be shown that, in line with existing results in experimental economics, in this game too, on average men resort more often to dishonest communication as compared to women. Yet, lies are larger in heterogenous groups, the largest (respectively lowest) lies being recorded by man (women) Proposers teamed with a woman (man) Responder.

Differences in how men (women) react when paired with same (opposite) gender partners have already been observed in standard Ultimatum Games with perfect information. Eckel and Grossman (2001) find that women make more generous offers than men, that offers made by women do not depend on the partner's gender, and that they are more likely to be accepted. Solnick (2001) finds that on average women and men do similar

\footnotetext{
${ }^{1}$ In the paper by Dreber and Johannesson (2008), receivers were informed about the gender of the sender, but the latter did not know that senders will get this information. Thus the decision of the sender, whether to lie or not, could not be influenced by the gender of the partner.

${ }^{2}$ Experimental economics have shown that men tend to be less risk averse than women (Croson and Gneezy (2009); Eckel and Grossman (2008)), and also have a stronger preference for competition (Niederle and Vesterlund (2007, 2011); Croson and Gneezy (2009)). Both these personal characteristics support the assumption according to which that men would adopt more aggressive communication strategies than women.

${ }^{3}$ The Ultimatum Game was developed by Güth et al. (1982). See Güth and Kocher (2014) and van Damme et al. (2014) for recent surveys. The asymmetric information version was introduced by Mitzkewitz and Nagel (1993) and was further extended by many other scholars.

${ }^{4}$ The strategy to overstate the endowment is hard to justify in this game, since Proposers who adopt it not only would bear the lying cost, but also would see chances to see their offer accepted falling.
} 
offers, but women make higher offers to man opposers. Also, Responders of both genders are more demanding when the opposer is female. In a $2 \times 2$ design - male/female and origin of Jewish immigrants to Israel (Ashkenazic / Sephardic) - Fershtman and Gneezy (2001) found that males (but not females) discriminate against Ashkenazic men (but not against women), offering them less than they do to Sephardic men. Our analysis will also allow to test whether these documented differences hold in our specific setting.

\section{Experimental design}

At the beginning of the experiment, subjects were matched in pairs at random without revealing their identity. Instructions were presented via computer interface and all interactions were computerized. ${ }^{5}$ Subject roles (i.e., Proposer or Responder) were randomly assigned. Each proposer played the game five times (rounds) against the same anonymous partner.

At the beginning of each round, the computer draws the Proposer's endowment $S$ among integers in the range of $[50 ; 100]$ Experimental Currency Units (ECUs) with the same probability. The statistical distribution of $S$ is common knowledge, but only Proposers know the actual endowment. They nonetheless can send an unverifiable message to the Responder about the amount of their endowment; the stated amount is denoted by $Z$. Truthful communication is equivalent to $Z=S$, and dishonest communication is equivalent to $Z \neq S$. The Proposer also makes an offer $R$ to the Responder. Like in a standard UG, at the end of the game the Responder can accept the offer $R$ (then the Proposer's payoff is $(S-R)$ ), or turn it down thus bringing payoffs of both players to zero.

As already mentioned, this study aims at analyzing the impact of gender interaction on the communication and pie sharing strategies. Thus, different from Besancenot et al. (2013), in this paper we manipulate the gender composition of the Proposer-Responder pairs, to create mixed pairs, man-man and woman-woman pairs. We ensure that students who participated in one treatment could not participate in another treatment (between subjects design). It was also important to ensure that team members were aware of the gender of their partner, while preserving anonymity and without conveying this information in a salient way. We thus followed the method used by Jung and Vranceanu (2015) in organizing sessions where only men (only women) were invited, and mixed-gender sessions with an equal number of men and women. In the single-gender sessions participants can clearly observe that only men (women) are present, so they realized that they were paired with a same-gender partner. In the mixed gender sessions, all pairs were mixed but individuals cannot observed it directly. Thus, to convey information on the gender of the partner in a non-directive way and without relaxing anonymity, at the beginning of the experiment, participants were asked to complete an electronic form concerning their "personal characteristics" - age, gender and level of education. Immediately thereafter, the information was communicated to the other team member as "basic information" about his/her partner. In our student population, ages and levels of education are not differentiating characteristics. The only distinctive characteristic was gender, but no emphasis was placed on this.

Participants were recruited from the student population of ESSEC Business School in

\footnotetext{
${ }^{5}$ The computer program was written in z-Tree (Fischbacher (2007)) by Delphine Dubart. Instructions are presented in the Appendix.
} 
Paris-Cergy (France), who answered to a call for paid decision experiments. All session were conducted at the Experimental Research Lab of the school; the first session was held on March 18, 2015, with a total of 12 male pairs, followed by the second session on March 19, 2015 with 11 female pairs; the third session was on April 3, 2015 with 11 mixed gender pairs, the fourth session was on May 12, 2015 with 4 mixed gender pairs, and the last session was held on May 12, 2015 with 8 mixed gender pairs and 5 male pairs. We thus gathered a total of 255 observations (51 per round). At the end of the experiment, we asked students whether they could recall the gender of their partner, and if so, what the gender was; one (out of 102 subjects) could not recall this. Observations related to this individual were excluded from further analyses.

Actual payoffs in one randomly chosen round were paid for real money, at an exchange rate of 10 euros for 100 experimental currency units. The test lasted for 20 minutes on average, and players earned 9.5 euros (including a 2 euros fixed participation amount).

\section{Results}

\subsection{Basic statistics}

Table 1 presents simple descriptive statistics for the full sample and the four groups of different gender compositions. We categorized our groups according to the gender of the Proposer and the gender of the Responder (in exactly this order) as MM for men (Proposers)-men (Responders), WW for women-women, MW for men-women, and WM for women-man. The endowment $S$ was generated by computer random sampling in the interval $[50 ; 100]$, therefore the mean of the endowment (75ECUs) does not differ across the groups. As already mentioned, the "stated" endowment is denoted by $Z$, and the offered amount is denoted by $R$.

$L I E_{-} D$ is an indicator variable, taking value 1 if the proposer had lied about the amount of endowment when sending the message $(Z \neq S)$, and 0 if else. The continuous variable $L I E=S-Z$, referred to as the "amount of lie", is a measure of Proposer's dishonesty. In a very small number of cases $(3.4 \%)^{6}$, Proposers overstated the actual endowment; as already mentioned, this strategy is hard to be rationalized in a model with lying costs and Bayesian Responders. Therefore, in further analyses we truncate these observations to the actual endowment (as if they were telling the truth).

$A C C$ is a indicator variable taking the value 1 if the Responder accepted the offer and 0 if else.

Let us firstly analyze the Proposers' behavior. Figure 1 presents the average all-round amount of the offers $R$ made by proposers across groups. On average, offers represent about $41 \%$ (31.06 out of 75.71) of the endowment, in line with standard outcome in other UG experiments. In our experiment, (R1) men tend to make higher offers (to both men or women) than women, who are the least generous with women. This results contrasts with early results from a perfect information UG by Eckel and Grossman (2001) who showed that women make more generous offers than men, or Solnick (2001), who observed that women make higher offer to men.

When analyzing lying behavior, we can distinguish between an "extensive margin", as the yes/no decision whether to understate the actual endowment $\left(L I E_{-} D=1\right)$, and the "intensive margin" or the amount of the lie, $L I E=S-Z$ conditional on choosing to lie.

\footnotetext{
${ }^{6} 9$ times out of 265 observations
} 
Table 1: Descriptive Statistics

\begin{tabular}{|c|c|c|c|c|c|}
\hline & count & mean & $\mathrm{sd}$ & $\min$ & $\max$ \\
\hline \multicolumn{6}{|c|}{ Full Sample } \\
\hline $\mathrm{S}$ & 250 & 75.71 & 13.95 & 50 & 100 \\
\hline $\mathrm{Z}$ & 250 & 65.61 & 11.53 & 50 & 100 \\
\hline $\mathrm{R}$ & 250 & 31.06 & 7.41 & 9 & 50 \\
\hline LIE_D & 250 & 0.69 & 0.46 & 0 & 1 \\
\hline LIE & 250 & 10.52 & 11.18 & 0 & 45 \\
\hline LIE cond. LIE_D=1 & 173 & 15.20 & 10.45 & 1 & 45 \\
\hline Accept & 250 & 0.76 & 0.43 & 0 & 1 \\
\hline \multicolumn{6}{|c|}{$\underline{\mathrm{MM}}$} \\
\hline $\mathrm{S}$ & 85 & 76.09 & 14.10 & 50 & 99 \\
\hline $\mathrm{Z}$ & 85 & 66.62 & 13.10 & 50 & 100 \\
\hline $\mathrm{R}$ & 85 & 32.01 & 7.83 & 10 & 50 \\
\hline LIE_D & 85 & 0.65 & 0.48 & 0 & 1 \\
\hline LIE & 85 & 10.28 & 11.45 & 0 & 45 \\
\hline LIE cond. LIE_D $=1$ & 55 & 15.89 & 10.63 & 1 & 45 \\
\hline Accept & 85 & 0.69 & 0.46 & 0 & 1 \\
\hline \multicolumn{6}{|c|}{$\underline{\mathrm{WW}}$} \\
\hline $\mathrm{S}$ & $5 \overline{5}$ & 75.62 & 12.68 & 51 & 100 \\
\hline $\mathrm{Z}$ & 55 & 64.98 & 10.22 & 50 & 90 \\
\hline $\mathrm{R}$ & 55 & 30.65 & 7.07 & 10 & 45 \\
\hline LIE_D & 55 & 0.67 & 0.47 & 0 & 1 \\
\hline LIE & 55 & 10.64 & 11.87 & 0 & 43 \\
\hline LIE cond. LIE_D=1 & 37 & 15.81 & 11.28 & 1 & 43 \\
\hline Accept & 55 & 0.85 & 0.36 & 0 & 1 \\
\hline \multicolumn{6}{|c|}{ MW } \\
\hline S & 55 & 74.71 & 15.64 & 51 & 100 \\
\hline $\mathrm{Z}$ & 55 & 63.89 & 10.56 & 50 & 100 \\
\hline $\mathrm{R}$ & 55 & 31.44 & 6.28 & 20 & 50 \\
\hline LIE_D & 55 & 0.71 & 0.46 & 0 & 1 \\
\hline LIE & 55 & 11.33 & 12.36 & 0 & 45 \\
\hline LIE cond. LIE_D $=1$ & 39 & 15.97 & 11.87 & 1 & 45 \\
\hline Accept & 55 & 0.82 & 0.39 & 0 & 1 \\
\hline \multicolumn{6}{|c|}{$\underline{\mathrm{WM}}$} \\
\hline S & 55 & 76.22 & 13.46 & 51 & 99 \\
\hline $\mathrm{Z}$ & 55 & 66.38 & 11.18 & 50 & 96 \\
\hline $\mathrm{R}$ & 55 & 29.62 & 8.03 & 9 & 48 \\
\hline LIE_D & 55 & 0.76 & 0.43 & 0 & 1 \\
\hline LIE & 55 & 9.95 & 8.80 & 0 & 40 \\
\hline LIE cond. LIE_D $=1$ & 42 & 13.02 & 7.81 & 1 & 40 \\
\hline Accept & 55 & 0.69 & 0.47 & 0 & 1 \\
\hline
\end{tabular}


Figure 1: Offer by Gender Composition

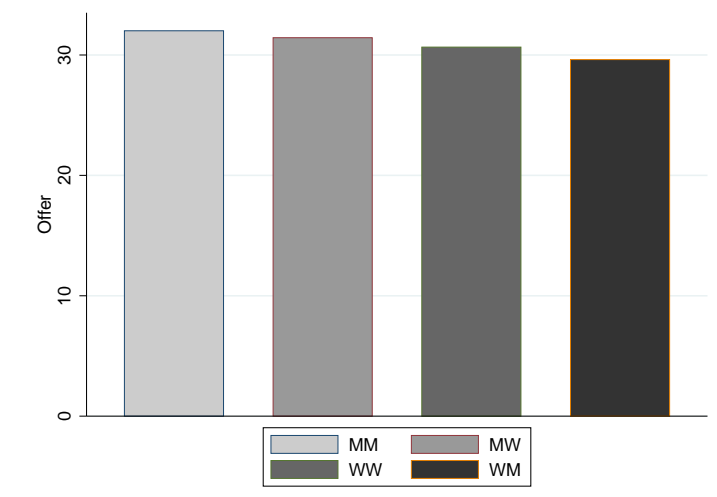

Figure 2 shows the all-round frequency of lying by gender group, and Figure 3 displays the average all-round average amount of lies, conditional on lying.

Figure 2: Frequency of Lying by Gender Composition

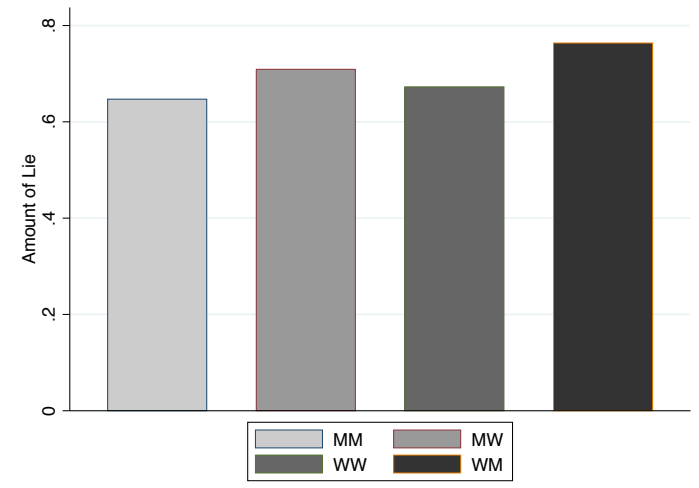

Figure 3: Amoung of Lie cond. on Lying by Gender Composition

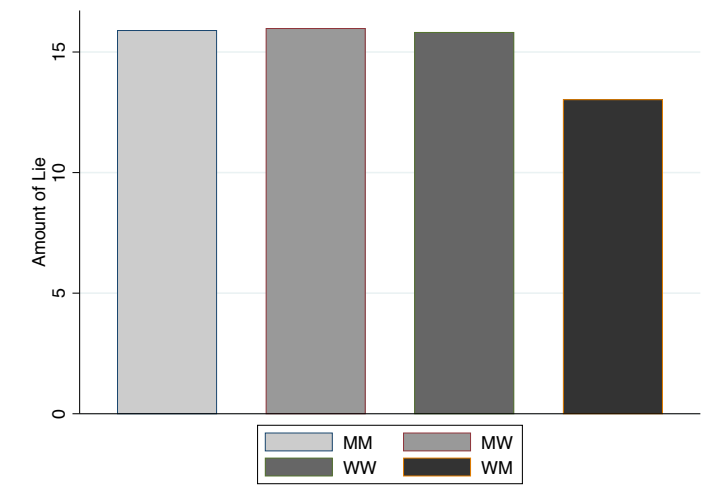

Lying by understating the actual endowment $S$ is a widespread strategy. Proposers made this choice in $65 \%-67 \%$ of the decisions taken in same gender pairs; the lying frequency raises to $71 \%-76 \%$ in mixed gender pairs. It turns out that (R2) both man and women would lie more often when paired the opposite gender Responder. ${ }^{7}$

However, conditional on lying, (R3) the average amount of lie submitted by women Proposers paired with men Responders is smaller than in all other groups (13 ECUs vs. more than 15.8 ECUs).

If we put together (R2) and (R3), in mixed groups both man and women Proposers will adopt more frequently the lying strategy (compared with homogenous groups), yet in the case of Women Proposers - Men Responders, the high frequency of lying (high extensive margin) is somehow offset by the lower average amount of lies (lower intensive margin).

Turning to Responders' behavior, results in Table 1 and Figure 4 show that whatever the gender of the partner, (R4) women's acceptance rate is higher than men's acceptance rate ( $82 \%-85 \%$ vs. $69 \%$, respectively) according to the basic statistics. This result differs from Solnick (2001) who, in a perfect information UG, showed that Responders are more demanding when the Proposer is female.

Regression analysis will allow us to check whether these four key results hold when

\footnotetext{
${ }^{7}$ This result will not receive statistical validity in subsequent regression analysis.
} 
Figure 4: Acceptance by Gender Composition

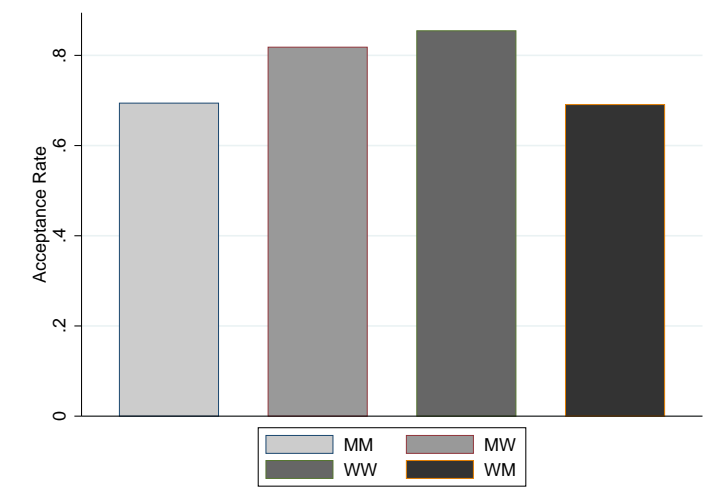

adding additional controls.

\subsection{Regression analysis}

\section{a/ Proposer Offer Strategy}

We first estimate an offer equation. The dependent variable is the amount of the offer made by the Proposer $i$ at round $t, S_{i t}$. Gender covariates are four indicator variables: $M M$ (respectively $M W$ ) takes the value 1 if the Proposer is a man paired with a man (respectively woman) Responder and zero if else; $W M$ (respectively $W W$ ) takes the value 1 if the Proposer is a woman paired with a men (respectively women) Responder, and zero if else. Other covariates are the endowment $S$ and the $L I E$, as well as the lagged amount of $L I E$ or acceptance decision $(A C C)$. Since our dataset has a panel structure, we implement a random-effects regression model in order to take into account individual random effects over periods.

Table 2 reports the output of the regression. The $W W$ group was set as the reference thus does not appears in the output table. Columns (1) and (2) are the regression models with and without the gender indicators, including the full five periods; Columns (3) and (4) include one round lagged terms $L I E_{-1}$ and $A C C_{-1}$, in order to control for possible path-dependent behavior.

As expected, the offer $R$ is increasing in the endowment $S$, with offers raising over the five rounds.

In line with the former result (R1), on average man Proposers make larger offers than women Proposers. This outcome can be explained either by preferences (men are more generous) of by the more pessimistic beliefs about the acceptance of lower offers. The analysis of the acceptance decision (Table 5) will show that man Responders tend to reject (identical) offers more often than women, an observation that would support the second explanation. Furthermore, men Proposers paired with women are the most generous (as shown by the coefficient of MW), while women Proposers teamed with man are the least generous (as shown by the negative coefficient of WM).

The offer is negatively correlated with the amount of the lie, as found by Besancenot et al. (2013). When understating the endowment by one ECU, Proposers reduce their offer by 0.5 ECU.

Finally, as expected, Proposers tend to reduce their offer if their past period offer was accepted.

b/ Proposer Communication Strategy 
Table 2: Offer Decision

\begin{tabular}{|c|c|c|c|c|}
\hline & (1) & $(2)$ & (3) & (4) \\
\hline & $\mathrm{R}$ & $\mathrm{R}$ & $\mathrm{R}$ & $\mathrm{R}$ \\
\hline S & $\begin{array}{c}0.546^{* * *} \\
(0.02)\end{array}$ & $\begin{array}{c}0.547^{* * *} \\
(0.02)\end{array}$ & $\begin{array}{c}0.534^{* * *} \\
(0.02)\end{array}$ & $\begin{array}{c}0.537^{* * *} \\
(0.03)\end{array}$ \\
\hline LIE & $\begin{array}{c}-0.506^{* * *} \\
(0.03)\end{array}$ & $\begin{array}{c}-0.509^{* * * *} \\
(0.03)\end{array}$ & $\begin{array}{c}-0.502^{* * *} \\
(0.03)\end{array}$ & $\begin{array}{c}-0.502^{* * *} \\
(0.04)\end{array}$ \\
\hline Period & $\begin{array}{c}0.423^{* * *} \\
(0.14)\end{array}$ & $\begin{array}{c}0.422^{* * *} \\
(0.15)\end{array}$ & $\begin{array}{c}0.395^{* *} \\
(0.18)\end{array}$ & $\begin{array}{c}0.403^{* *} \\
(0.16)\end{array}$ \\
\hline MM & & $\begin{array}{l}0.917^{*} \\
(0.51)\end{array}$ & $\begin{array}{l}0.993 \\
(0.61)\end{array}$ & $\begin{array}{l}0.998^{*} \\
(0.58)\end{array}$ \\
\hline MW & & $\begin{array}{c}1.631^{* * *} \\
(0.55)\end{array}$ & $\begin{array}{c}1.601^{* * *} \\
(0.52)\end{array}$ & $\begin{array}{c}1.588^{* * *} \\
(0.55)\end{array}$ \\
\hline WM & & $\begin{array}{c}-1.716^{* * *} \\
(0.57)\end{array}$ & $\begin{array}{c}-1.459^{* *} \\
(0.59)\end{array}$ & $\begin{array}{c}-1.421^{* *} \\
(0.57)\end{array}$ \\
\hline $\mathrm{ACC}_{-1}$ & & & $\begin{array}{c}-1.280^{* * *} \\
(0.50)\end{array}$ & $\begin{array}{c}-1.276^{* * *} \\
(0.44)\end{array}$ \\
\hline $\mathrm{LIE}_{-1}$ & & & & $\begin{array}{l}0.021 \\
(0.02)\end{array}$ \\
\hline _cons & $\begin{array}{c}-6.187^{* * *} \\
(1.37)\end{array}$ & $\begin{array}{c}-6.560^{* * *} \\
(1.55)\end{array}$ & $\begin{array}{c}-4.678^{* * *} \\
(1.63)\end{array}$ & $\begin{array}{c}-5.152^{* *} \\
(2.16)\end{array}$ \\
\hline chi2 & 770.764 & 748.352 & 855.075 & 498.144 \\
\hline $\mathrm{N}$ & 250 & 250 & 200 & 200 \\
\hline $\mathrm{r} 2 \_\mathrm{w}$ & 0.805 & 0.805 & 0.858 & 0.860 \\
\hline r2_b & 0.455 & 0.527 & 0.556 & 0.548 \\
\hline r2_o & 0.675 & 0.701 & 0.734 & 0.731 \\
\hline
\end{tabular}

$* \mathrm{p}<0.10,{ }^{* *} \mathrm{p}<0.05,{ }^{* * *} \mathrm{p}<0.01$

Robust S.E Clustered at the individual level.

We can turn now our attention to the communication strategies. As already mentioned, lying involves both an "extensive margin" (the frequency of false statement) and an "intensive" margin (the amount of understatement).

Table 3 provides the output of a random-effects regression model with LIE_D as the dependent variable. This emphasizes the impact of the group interaction on the communication strategy (honest/dishonest). The main covariates are the gender indicator variables MM, MW, and WM, with WW as the reference group.

Data are only weakly consistent with (R2): the frequency of lying is somewhat higher in mixed groups as compared to homogenous groups, and is not significantly different between MM and WW groups. This may suggest that the gender composition matter less in deciding whether to lie or not, than in deciding about the amount of lying once they choose to lie (i.e. the extensive margin is relatively small as compared to the intensive margin in lying behavior).

Table 4 presents the random effects model of a "lie equation conditional on lying" aiming to analyze the impact of the gender composition on the intensive margin of lying behavior. The dependent variable is the amount of the lie, $L I E=Z-S>0$. Covariates 
Table 3: Frequency of Lying

\begin{tabular}{lcccc}
\hline \hline & $(1)$ & $(2)$ & $(3)$ & $(4)$ \\
& LIE_D & LIE_D & LIE_D & LIE_D \\
\hline $\mathrm{R}$ & $-0.036^{* * *}$ & $-0.036^{* * *}$ & $-0.042^{* * *}$ & $-0.041^{* * *}$ \\
& $(0.00)$ & $(0.00)$ & $(0.00)$ & $(0.00)$ \\
$\mathrm{S}$ & $0.020^{* * *}$ & $0.020^{* * *}$ & $0.022^{* * *}$ & $0.022^{* * *}$ \\
& $(0.00)$ & $(0.00)$ & $(0.00)$ & $(0.00)$ \\
Period & 0.024 & 0.024 & 0.027 & 0.027 \\
& $(0.01)$ & $(0.02)$ & $(0.02)$ & $(0.02)$ \\
MM & & 0.014 & 0.029 & 0.029 \\
& & $(0.05)$ & $(0.07)$ & $(0.06)$ \\
MW & & 0.083 & 0.059 & 0.057 \\
& & $(0.06)$ & $(0.07)$ & $(0.07)$ \\
WM & & 0.041 & 0.022 & 0.026 \\
& & $(0.06)$ & $(0.07)$ & $(0.06)$ \\
ACC & & & -0.044 & -0.045 \\
& & & $(0.07)$ & $(0.06)$ \\
LIE & & & & 0.002 \\
& & & & $(0.00)$ \\
cons & 0.199 & 0.166 & 0.251 & 0.196 \\
& $(0.15)$ & $(0.15)$ & $(0.17)$ & $(0.17)$ \\
\hline chi2 & 160.652 & 168.486 & 133.915 & 108.717 \\
N & 250.000 & 250.000 & 200.000 & 200.000 \\
r2_w & 0.312 & 0.312 & 0.375 & 0.371 \\
r2_b & 0.359 & 0.368 & 0.400 & 0.425 \\
r2_o & 0.333 & 0.337 & 0.387 & 0.397 \\
\hline \hline \multirow{2}{*}{ p } & & & &
\end{tabular}

$* \mathrm{p}<0.10,{ }^{* *} \mathrm{p}<0.05,{ }^{* * *} \mathrm{p}<0.01$

Robust S.E Clustered at the individual level.

are the same as before. Obviously, the set of observations comprises now only games where the Proposer has understated the amount of the endowment (we exclude all cases of truthful reporting).

As expected, the amount of lying is proportional to the endowment. Indeed, Responders' trust in the message must be decreasing in the stated amount; if the Proposer claims to get 100ECU (the upper bound), this message can only be true; if he claims he got 50 (the lower bound), Responders' doubts about the truthfulness of this claim should be the highest. Thus the optimal claim should be somewhere between the endowment and the lower bound. The higher the endowment, the higher the lie can be.

The analysis of the coefficients of the gender indicator variables corroborate our result (R3). First of all, men will understate the endowment by a bigger difference if their partner is a woman. Second, women tend to lie less as an amount, and this amount of lie is significantly smaller when they play against a men Responder. ${ }^{8}$

\footnotetext{
${ }^{8}$ We present in Appendix 2 the output of the random effects tobit regression model, in order take into account that the amount of lie is a left censorerd variable. The coefficients are similar to those in Table 4 .
} 
Table 4: Amount of Lie conditional on Lying

\begin{tabular}{lcccc}
\hline \hline & $(1)$ & $(2)$ & $(3)$ & $(4)$ \\
& LIE & LIE & LIE & LIE \\
\hline $\mathrm{R}$ & $-1.084^{* * *}$ & $-1.093^{* * *}$ & $-1.242^{* * *}$ & $-1.187^{* * *}$ \\
& $(0.12)$ & $(0.13)$ & $(0.14)$ & $(0.12)$ \\
$\mathrm{S}$ & $0.847^{* * *}$ & $0.850^{* * *}$ & $0.899^{* * *}$ & $0.884^{* * *}$ \\
& $(0.04)$ & $(0.04)$ & $(0.05)$ & $(0.04)$ \\
Period & -0.014 & -0.010 & 0.107 & 0.081 \\
& $(0.32)$ & $(0.25)$ & $(0.44)$ & $(0.38)$ \\
MM & & 1.532 & $2.312^{* *}$ & $2.333^{* *}$ \\
& & $(1.07)$ & $(1.02)$ & $(1.05)$ \\
MW & & $2.670^{* *}$ & $2.916^{* * *}$ & $2.960^{* * *}$ \\
& & $(1.05)$ & $(0.92)$ & $(1.02)$ \\
WM & & $-2.558^{* *}$ & $-2.043^{* *}$ & $-1.944^{*}$ \\
& & $(1.02)$ & $(1.01)$ & $(1.04)$ \\
ACC & & & -0.514 & -0.463 \\
& & & $(1.06)$ & $(1.04)$ \\
LIE & & & & 0.018 \\
& & & & $(0.04)$ \\
cons & $-18.915^{* * *}$ & $-19.420^{* * *}$ & $-19.285^{* * *}$ & $-19.918^{* * *}$ \\
& $(2.24)$ & $(2.98)$ & $(3.41)$ & $(3.64)$ \\
\hline chi2 & 631.625 & 471.754 & 489.111 & 502.994 \\
N & 173 & 173 & 139 & 139 \\
r2_w & 0.784 & 0.784 & 0.826 & 0.822 \\
r2_b & 0.606 & 0.663 & 0.564 & 0.574 \\
r2_o & 0.668 & 0.706 & 0.682 & 0.687 \\
\hline \hline
\end{tabular}

$* \mathrm{p}<0.10,{ }^{* *} \mathrm{p}<0.05,{ }^{* * *} \mathrm{p}<0.01$

Robust S.E Clustered at the individual level.

Finally, from Column 4, it can be seen that a Proposer who lied in the past tends to lie more, which reveals the consistency of the individual characteristics (although insignificant).

\section{b/ Responder Behavior}

Table 5 presents the random effects regression model of the Responder acceptance decision. The dependent variable is the $A C C$ indicator variable, taking the value 1 if the offer was accepted. We recall that the Responder "sees" the offer $R$ and the message $M$, but does not knows the endowment of the Proposer.

As emphasized by Besancenot et al. (2013), contrary to Proposers' beliefs, their message has little impact on Responders' acceptance decision who care only about the actual amount of the offer. We also checked, and found that interaction terms between the message and the gender variables are not significant. This result is in line with findings by Dreber and Johannesson (2008), who fond no gender differences in receiver's trustfulness, no matter whether the sender was a man or a woman.

The analysis of the gender indicator variables corroborates our former finding (R4): compared to woman Responders, man Responders accept offers significantly less often 
Table 5: Acceptance Decision

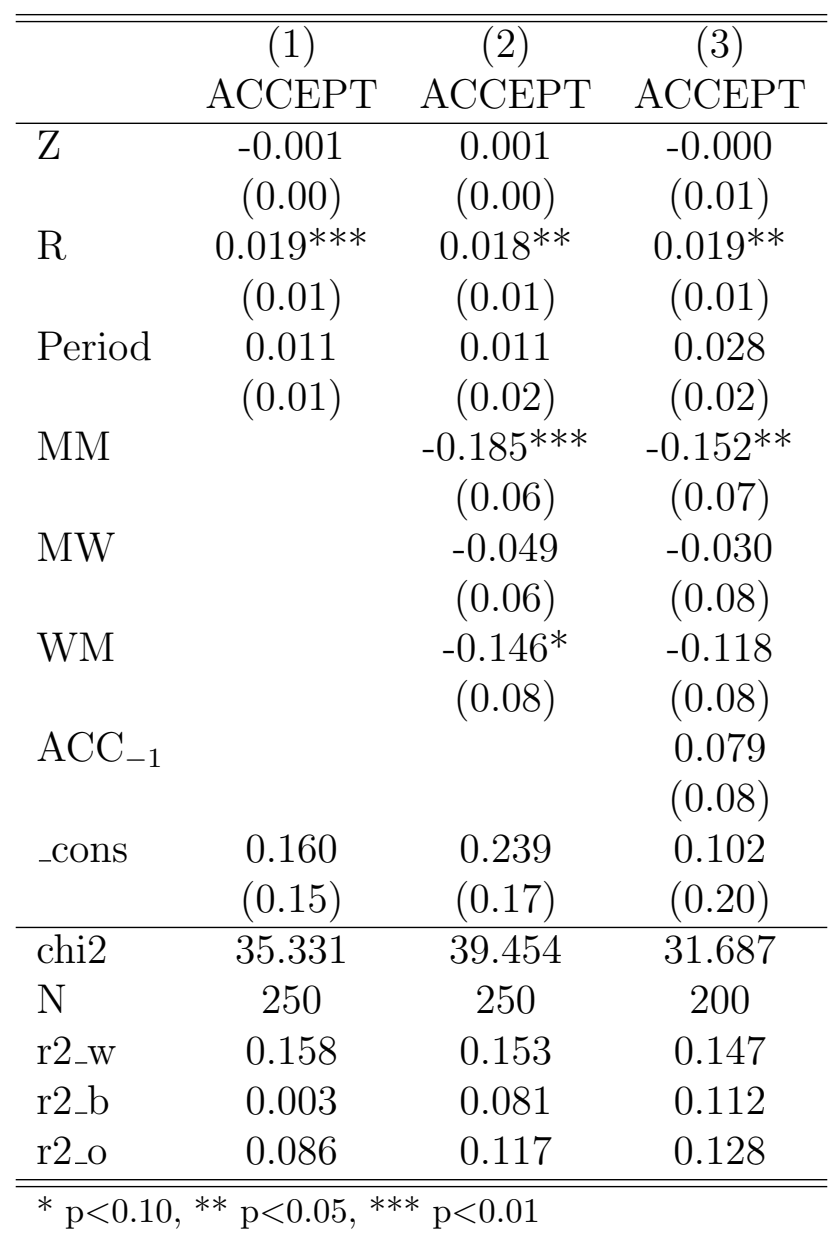

Robust S.E Clustered at the individual level.

(according to the negative coefficient of $M M$ and $W M$ ).

Furthermore, man Responders are the most demanding when they are paired with another man, while woman Responders paired with another woman are the most complacent (but the difference with $W W$ is not significant).

\section{Conclusion}

This paper uses an UG with asymmetric information to analyze players' communication strategies, while taking into account all possible gender interactions. Allowing for potentially dishonest communication appears to have an impact on the pie sharing strategies. Contrary to findings by Eckel and Grossman (2001) and Solnick (2001) from a perfect information experiment, in our study men make higher offers than women; the highest offers are made by men paired with women Responders, and the lowest by women paired with men Responders. All things equal, the acceptance rate of man Responders is lower than the acceptance rate of woman Responders. In this sense, men appearance of generosity might be explained by their more pessimistic beliefs about the acceptance rate of low offers, as validated by their own behavior in the Responder's role. 
Lying by understating the endowment is the most widespread strategy, as implemented in $76 \%$ of the games (overstatement occurred only in $3.9 \%$ of the games, the rest being truth-telling). Lies induce lower offers: on average, for each ECU of lie, Proposers will reduce their offer by 0.54 ECUs.

We provide weak evidence that the frequency of lying is higher in mixed groups than in homogenous groups. However, studying only cases where lying was observed (the extensive margin of lying), on average, whatever the gender of the partner, the amount of lies submitted by women is lower than the amount of lies submitted by men, a result in line with existing experimental evidence ((Gill et al. (2013); Conrads et al. (2013); Dreber and Johannesson (2008))). Furthermore, female Proposers paired with a male Responder will submit the "smallest lies", while male Proposers paired with a female Responder will submit the "biggest lies", with an intermediate level of lying in homogenous groups.

It is, of course, difficult to infer general conclusions from such simple experiments. However, the existence of a gender effect in lying behavior as observed within a population of homogenous subjects on all dimensions but gender, raises an important research question that worth being taken further. The question of the best organization of teams cannot ignore the quality of communication, and the "production of truth". Common sense would argue that truth-telling is an important value for the good manager (Solomon (1992)). In our specific context, gender homogenous teams turned out to provide the most supportive environment for truth-telling.

\section{Acknowledgments}

The authors would like to thank the LABEX MME-DII (http://labex-mme-dii.ucergy.fr/) and the ESSEC Research Center for having funded this research project. They are grateful to Delphine Dubart for her technical assistance.

\section{References}

Anbarci, N., N. Feltovich And M. Y. Gürdal, "Lying about the price? Ultimatum bargaining with messages and imperfectly observed offers," Journal of Economic Behavior and Organization 116 (2015), 346-360.

ArIEly, D., The (Honest) Truth about Dishonesty (Harper Collins, 2012).

Besancenot, D., D. Dubart and R. Vranceanu, "The value of lies in an ultimatum game with imperfect information," Journal of Economic Behavior and Organization 93 (2013), 239-247.

Boles, L. R. T. A. C., Terry and J. K. Murnighan, "Deception and retribution in repeated ultimatum bargaining," Organizational Behavior and Human Decision Processes 83 (2000), 235-259.

Charness, G. And M. Dufwenberg, "Promises and partnership," Econometrica 74 (2006), 1579-1601.

, "Bare promises: An experiment," Economics Letters 107 (2010), 281-283.

Conrads, J., B. Irlenbusch, R. M. Rilke and G. Walkowitz, "Lying and team incentives," Journal of Economic Psychology 34 (2013), 1-7. 
Croson, R. And U. Gneezy, "Gender differences in preferences," Journal of Economic Literature 47(2) (2009), 1-27.

Croson, T. L. B. J. K. M., Rachel T. A., "Cheap talk in bargaining experiments: Lying and threats in ultimatum games," Journal of Economic Behavior and Organization 51 (2003), 143-159.

De Paulo, B., D. Kashy, S. Kirkendol, M. Wyer and J. Epstein, "Lying in everyday life.," Journal of Personality and Social Psychology 70 (1996), 979-995.

Dreber, A. And M. Johannesson, "Gender differences in deception," Economics Letters 99 (April 2008), 197-199.

ECKel, C. C. And P. J. Grossman, "Chivalry and solidarity in ultimatum games," Economic Inquiry 39 (2001), 171-188.

- "Men, women and risk Aversion: Experimental evidence," Handbook of Experimental Economics Results 1 (2008), 1061-1073.

Erat, S. And U. Gneezy, "White lies," Management Science 58 (2012), 723-733.

Feldman, R. S., J. A. Forrest and B. R. Happ, "Self-Presentation and Verbal Deception: Do Self-Presenters Lie More?," Basic and Applied Social Psychology 24 (2002), 163-170.

Fershtman, C. And U. Gneezy, "Discrimination in a segmented society: An experimental approach," The Quarterly Journal of Economics 116 (February 2001), 351-377.

FischBACHER, U., "z-Tree: Zurich toolbox for ready-made economic experiments," $E x$ perimental Economics 10 (June 2007), 171-178.

Gill, D., V. Prowse And M. Vlassopoulos, "Cheating in the workplace: An experimental study of the impact of bonuses and productivity," Journal of Economic Behavior and Organization 96 (2013), 120-134.

Gneezy, U., "Deception: The role of consequences," American Economic Review 95 (2005), 384-394.

Güth, W. AND M. G. Kocher, "More than thirty years of ultimatum bargaining experiments: Motives, variations, and a survey of the recent literature," Journal of Economic Behavior $\&$ Organization 108 (2014), 396-409.

Güth, W., R. Schmittberger and B. Schwartze, "An experimental analysis of the ultimatum bargaining," Journal of Economic Behavior and Organization 3 (1982), $367-388$.

Hao, L. And D. Houser, "Honest lies," GMU Working Paper in Economics (2010).

Jung, S. And R. VRanceanu, "Gender Interaction in Teams: Experimental Evidence on Performance and Punishment Behavior," ESSEC WP1513 (2015).

Kriss, P. H., R. Nagel and R. A. Weber, "Implicit vs. explicit deception in ultimatum games with incomplete information," Journal of Economic Behavior \& Organization 93 (2013), 337-346. 
Lundquist, T., T. Ellingsen, E. Gribbe and M. Johannesson, "The aversion to lying," Journal of Economic Behavior \& Organization 70 (May 2009), 81-92.

Mitzkewitz, M. AND R. NAGEL, "Experimental results on ultimatum games with imperfect information," International Journal of Game Theory 22 (1993), 171-198.

Niederle, M. And L. Vesterlund, "Do women shy away from competition? Do men compete too much?," Quarterly Journal of Economics 122 (08 2007), 1067-1101.

, "Gender and competition," Annual Review in Economics 3 (2011), 601-630.

SAnchez-Pages, S. And M. Vorsatz, "An experimental study of truth-telling in a sender-receiver game," Games and Economic Behavior 61 (October 2007), 86-112.

Solnick, S. J., "Gender differences in the ultimatum game.," Economic Inquiry 39(2) (2001), 189-200.

Solomon, R. C., Ethics and Excellence: Cooperation and Integrity in Business (Oxford University Press, 1992).

van Damme, E., K. G. Binmore, A. E. Roth, L. Samuelson, E. Winter, G. E. Bolton, A. Ockenfels, M. Dufwenberg, G. Kirchsteiger, U. Gneezy And M. G. Kocher, "How Werner Güth's ultimatum game shaped our understanding of social behavior," Journal of Economic Behavior and Organization 108 (2014), 292-318.

VAnBerG, C., "Why do people keep their promises? An experimental test of two explanations," Econometrica 76 (2008), 1467-1480.

\section{APPENDIX 1. Instructions ${ }^{9}$}

\section{Screen 1.}

Good morning. Thank you for participating in this experiment. Please read these instructions carefully and, should you have any questions, raise your hand and call the administrator. Communication between participants is forbidden. Please turn off cellular phones. A payment in cash will be provided at the end of the session. In this experiment you will be paired at random with another person present in this room; pairing is strictly anonymous. Identities of the persons who interact will never be revealed. You will play the same game for five rounds with the same partner.

\section{Screen 2. Personal characteristics}

-You are: [A man / A woman]

-Your age is $[\mathrm{X}]$

-Your education level is: [Baccalaureate $+1,+2,+3,+4+5,+6$ or more years of education]

\section{Screen 3. About your partner}

-The gender of the partner is: [man/women]

-The age of the partner is: $[\mathrm{X}]$

-The education level of the partner is: [Baccalaureate $+1,+2,+3,+4+5,+6$ or more years

\footnotetext{
${ }^{9}$ Translated from French.
} 
of education]

\section{Screen 4. General information}

The experiment presents an interaction between two individuals on how to share a sum of money, denominated in ECU (for Experimental Currency Units) At the beginning of the game, one of the two players gets an endowment. He/She must then make an offer to the other on how to divide this amount between them. For instance, if he/she receives 100 ECUs, he/she can make an offer 10, that is a division 90:10. Then the other player can either accept this offer or reject it. If accepted, the first player who made the offer keeps the 90 ECUs and the second player who accepted the offer keeps the 10 ECUs; if rejected, both players get nothing. Thus by giving up his/her own gain, the second player can inflict a loss to the former. In this game, the player who receives the offer (Player 2), will never learn the exact amount received by the first player (Player1). He/She only knows that the amount is chosen by the computer, with equal chances, among the integers in the set [50, 100]. Before making his offer, Player 1 must sent a message to Player 2, indicating the amount he/she got at that round. Player 2 cannot verify this information (and Player 1 knows this).

\section{Screen 5. Some clarification questions}

These questions aim at helping you to better understand the rule of the game, by means of some fictitious examples.

1. You are the person who receives the offer (your are therefore Player 2).

Assuming that you know that Player 1 got 100 ECUs, if he offer you 25 ECU (75:25), would you accept this offer ? (Yes/No)

Assuming that you know that Player 1 got 50 ECUs, if he offer you 25 ECU (25:25), would you accept this offer? (Yes/No)

2. You are the person who makes the offer (you are therefore Player 1)

Assuming that you receive 90 ECUs, but Player 2 only knows that you get a sum in the interval $[50,100]$,

- What amount would you claim to have obtained ? [...]

- How much money would you offer him/her ? [...]

\section{Screen 6. The rule of the game}

Step 0: At the beginning of the game, Player 1 receives an amount $S$ drawn at random by the computer in the interval $[50,100]$. Every integer has equal chances to be chosen. Player 2 will never learn this amount, but knows that it is draw from the interval $[50,100]$ with equal chances.

Step 1. Player 1 offers to Player 2 an amount $R$ between 0 and $Y$. He/She also sends a message $M$ to Player 2, where he/she makes a statement about his endowment $S$.

Step 3. Player 2 learns the offer $R$ and the message about $S$, and decides whether to accept/reject this offer. If he/she accepts, he/she gets $R$ and Player 1 gets $(S-R)$, if he rejects this offer, both players get nothing. Player 2 will not be able to verify the information about the actual amount received by Player 1.

You will play this game five times in a row.

One round chosen at random will be remunerated in cash at the end of the experiment, 
at the exchange rate $100 \mathrm{ECU}=10$ euros.

\section{Screen 7a. The decision}

You are Player 1.

Following a random draw by the computer in the interval [50,100], you get the amount $[S]$. You must make an offer $R$ to Player 2 , in the interval $[0, S]$.

You will also send him/her a message about the money you got. Player 2 will not be able to verify your claim.

If at the next stage, Player 2 accepts the offer, you will gain $(S-R)$ and he/she gains $R$. If he rejects your offer, both of you will get zero.

Attention please. Actual decision.

For this round, the computer provides you with [...] ECU.

What amount do you declare to Player 2? [...]

What offer do you submit to Player 2? [...]

\section{Screen 7b. The decision}

You are Player 2.

At the previous stage, Player 1 got an amount in the interval [...].

He/She informs you that he got [...] ECUs

He/She makes you an offer of [...] ECUs

You must decide whether to accept or not this offer. If you reject this offer, gains of both of you are zero.

Make your decision now: [Accept] - [Reject]

\section{Screen 8a. Results}

Results. You are Player 2. Player 1 proposed [R]. You accepted (rejected) his offer. Your gain for this round is $[R]$ (or 0$)$.

\section{Screen 8b. Results}

Results. You are Player 1. You proposed [R]. Player 2 accepted (rejected) your offer. Your gain for this round is $[\mathrm{Y}-\mathrm{R}]$ (or 0$)$

\section{At the end of the experiment (after the 5 rounds) \\ Question}

Your partner was:

-[A man, A woman, Don't know]

\section{Last screen}

Thank you for having participated in this experiment.

The total gain for the experiment is [ ] euros. 


\section{APPENDIX 2. Random Effects Tobit Left-Censored regression of the extensive margin in lying}

\begin{tabular}{|c|c|c|c|c|}
\hline & LIE & LIE & LIE & LIE \\
\hline $\mathrm{R}$ & $\begin{array}{c}-1.127^{* * *} \\
(0.13)\end{array}$ & $\begin{array}{c}-1.112^{* * *} \\
(0.12)\end{array}$ & $\begin{array}{c}-1.286^{* * *} \\
(0.17)\end{array}$ & $\begin{array}{c}-1.283^{* * *} \\
(0.18)\end{array}$ \\
\hline $\mathrm{S}$ & $\begin{array}{c}0.860^{* * *} \\
(0.05)\end{array}$ & $\begin{array}{c}0.856^{* * * *} \\
(0.04)\end{array}$ & $\begin{array}{c}0.913^{* * *} \\
(0.05)\end{array}$ & $\begin{array}{c}0.914^{* * *} \\
(0.05)\end{array}$ \\
\hline Period & $\begin{array}{l}0.010 \\
(0.26)\end{array}$ & $\begin{array}{l}0.001 \\
(0.27)\end{array}$ & $\begin{array}{l}0.139 \\
(0.42)\end{array}$ & $\begin{array}{l}0.147 \\
(0.42)\end{array}$ \\
\hline MM & & $\begin{array}{l}1.519 \\
(0.94)\end{array}$ & $\begin{array}{c}2.301^{*} \\
(1.19)\end{array}$ & $\begin{array}{c}2.311^{* *} \\
(1.17)\end{array}$ \\
\hline MW & & $\begin{array}{c}2.661^{* * *} * \\
(0.92)\end{array}$ & $\begin{array}{c}2.894^{* *} \\
(1.32)\end{array}$ & $\begin{array}{c}2.916^{* *} \\
(1.18)\end{array}$ \\
\hline WM & & $\begin{array}{c}-2.567^{* *} \\
(1.10)\end{array}$ & $\begin{array}{l}-2.071 \\
(1.38)\end{array}$ & $\begin{array}{l}-2.021 \\
(1.33)\end{array}$ \\
\hline $\mathrm{ACC}_{-1}$ & & & $\begin{array}{l}-0.560 \\
(1.11)\end{array}$ & $\begin{array}{l}-0.549 \\
(1.25)\end{array}$ \\
\hline $\mathrm{LIE}_{-1}$ & & & & $\begin{array}{l}0.013 \\
(0.05)\end{array}$ \\
\hline _cons & $\begin{array}{c}-18.713^{* * * *} \\
(2.72)\end{array}$ & $\begin{array}{c}-19.316^{* * *} \\
(2.58)\end{array}$ & $\begin{array}{c}-19.116^{* * *} \\
(4.33)\end{array}$ & $\begin{array}{c}-19.445^{* * *} \\
(4.47)\end{array}$ \\
\hline \multicolumn{5}{|l|}{ sigma_u } \\
\hline _cons & $\begin{array}{c}3.973^{* * * *} \\
(0.53)\end{array}$ & $\begin{array}{c}3.419 * * * \\
(0.51)\end{array}$ & $\begin{array}{c}3.945^{* * *} \\
(0.71)\end{array}$ & $\begin{array}{c}3.933^{* * *} \\
(0.71)\end{array}$ \\
\hline \multicolumn{5}{|l|}{ sigma_e } \\
\hline _cons & $\begin{array}{c}4.510^{* * *} \\
(0.30)\end{array}$ & $\begin{array}{c}4.530^{* * * *} \\
(0.32)\end{array}$ & $\begin{array}{c}4.306^{* * *} \\
(0.37)\end{array}$ & $\begin{array}{c}4.307^{* * *} \\
(0.42)\end{array}$ \\
\hline chi2 & 362.170 & 518.597 & 380.391 & 475.640 \\
\hline $\mathrm{N}$ & 173.000 & 173.000 & 139.000 & 139.000 \\
\hline
\end{tabular}




\section{ESSEC Business School}

Avenue Bernard Hirsch

CS 50105 Cergy

95021 Cergy-Pontoise Cedex

France

Tél. + 33 (0)134433000

Fax + $33(0) 134433001$

www.essec.fr

ESSEC Executive Education

CNIT BP 230

92053 Paris-La Défense

France

Tél. + 33 (0)1 46924900

Fax +33(0)1 46924990

www.executive-education.essec.fr

\section{Contact:}

ESSEC Asia-Pacific

100 Victoria Street

National Library \# 13-02

Singapore 188064

Têl. +65 68849780

Fax +6568849781

www.essec.edu/asia

Research Center +33 (0)134433358 research.center@essec.fr

\section{E}

